\title{
Use of Remote Sensing Data in Evaluating the Extent of Anthropogenic Activities and their Impact on Lake Naivasha, Kenya
}

\author{
Simon M. Onywere ${ }^{1 * *}$, John M. Mironga ${ }^{2}$, Immaculate Simiyu ${ }^{3}$ \\ ${ }^{1}$ School of Environmental Studies, Department of Environmental Planning and Management, Kenyatta University, P.O. \\ Box 43844-00100, Nairobi, Kenya \\ ${ }^{2}$ Department of Geography, Egerton University, P.O. Box 536-20115, Njoro, Kenya \\ ${ }^{3}$ National Environmental Management Authority, P.O. Box 67839-00200, Nairobi, Kenya
}

\begin{abstract}
This study investigated the anthropogenic activities in Lake Naivasha Basin and how they are influencing the quality of water resources. The poor quality of water in the lake is seen from the presence of water hyacinth (Eichhornia crassipes) and is a reflection of nutrient rich waters. The water hyacinth in Lake Naivasha is associated with major negative economic and ecological impacts. The intensity of land use within the basin was mapped from multispectral Landsat satellite imagery of 1986 (TM) and 2000 (ETM) and SPOT imagery $10 \mathrm{~m}$ (resolution) of 2007. From interpreted data, the surface area of the Main Lake has decreased from $134.9 \mathrm{~km}^{2}$ in 1986 to $117.5 \mathrm{~km}^{2}$ in 2007 (12.9\%); that of papyrus and wetland grasslands along the lake shore decreased from $54.6 \mathrm{~km}^{2}$ to $34.3 \mathrm{~km}^{2}(37.2 \%)$ and that of the horticultural and irrigated farms increased by $103.3 \%$ from $45.1 \mathrm{~km}^{2}$ to $91.7 \mathrm{~km}^{2}$ in the same period, placing great pressure on both the quality and quantity of the lake's water resources. Information obtained from the Fisheries Department in Lake Naivasha show that the fishery production declined from 513 to 110 tons in the period considered. The Naivasha Municipal Council records indicate a 30\% decline in the water it supplies to Naivasha Town from 10,000 $\mathrm{m}^{3}$ to $7,000 \mathrm{~m}^{3}$ in the same period despite the increase in population. The decline was attributed to many factors among them the presence of water hyacinth and the decline in water quantity due to increased human activities.
\end{abstract}

Keywords: Anthropogenic activities, wetland, water hyacinth (Eichhornia crassipes), invasive species.

\section{INTRODUCTION}

Lake Naivasha occupies an important position in Kenya's economy because of the multi-million cut-flower industry flourishing at the riparian areas of the lake [1]. It is an important area for the production of fish, livestock and geothermal power [2] and is the main source of water for domestic use and for irrigation. Because of its biodiversity the lake was identified and named a Ramsar site in 1995 [3]. The lake is a fresh water lake in an otherwise markedly alkaline series of lakes in the Rift Valley floor [4]. The freshness of the water is attributed to incoming flow from Malewa and Gilgil rivers and to losses of solutes through seepage into the surrounding pumiceous formations. To some extent the freshness is also attributed to geochemical and biochemical sedimentation. In a study on major ion chemistry [5] estimated that the amount of water loss by seepage from Lake Naivasha was 5\% in 1973, 11\% in 1974 and $20 \%$ in 1975.

Despite its importance and role as a major tourist attraction and its use for boating and water sports, the lake faces

\footnotetext{
*Address correspondence to this author at the School of Environmental Studies, Department of Environmental Planning and Management, Kenyatta University, P.O. Box 43844-00100, Nairobi, Kenya;

Tel: +254-20-8710901/9; Fax: +254-20-8711575;

E-mail: onyweres@yahoo.com
}

enormous challenges from anthropogenic activities. The urban, peri-urban and rural populations have placed pressure on the lake's resources (water, fish, wildlife, and forest). The diverse farming activities within the Lake's basin affect the quantity and quality of water [6]. This is reflected in high levels of siltation and pollution of surface water as seen from the presence of high levels of nitrates, phosphates, BOD, and turbidity of the water [7]. It therefore means there is lack of adequate supply of clean water to the riparian communities.

The principal surface influx to Lake Naivasha is through Gilgil and Malewa Rivers flowing in from the north, down Bahati and Kinangop escarpments, respectively. The lake's catchment covers an area of $3320 \mathrm{~km}^{2}$. Malewa River contributes about $90 \%$ of the lake's recharge and most of the rest is contributed by Gilgil River [8]. Within the catchment there are worrying trends of land cover destruction that is impacting negatively on the lake and reflected on the proliferation of water hyacinth (Eichhornia crassipes) infestation [9]. The Lake Naivasha drainage basin, presents a good example of localities that have undergone extensive land use and land cover changes since the attainment of independence and a subsequent rise in its population. These transformations have been a threat to the sustainability of its natural resource endowments, in the figure of the lake itself and land, which are the pillar of its economic growth. The 


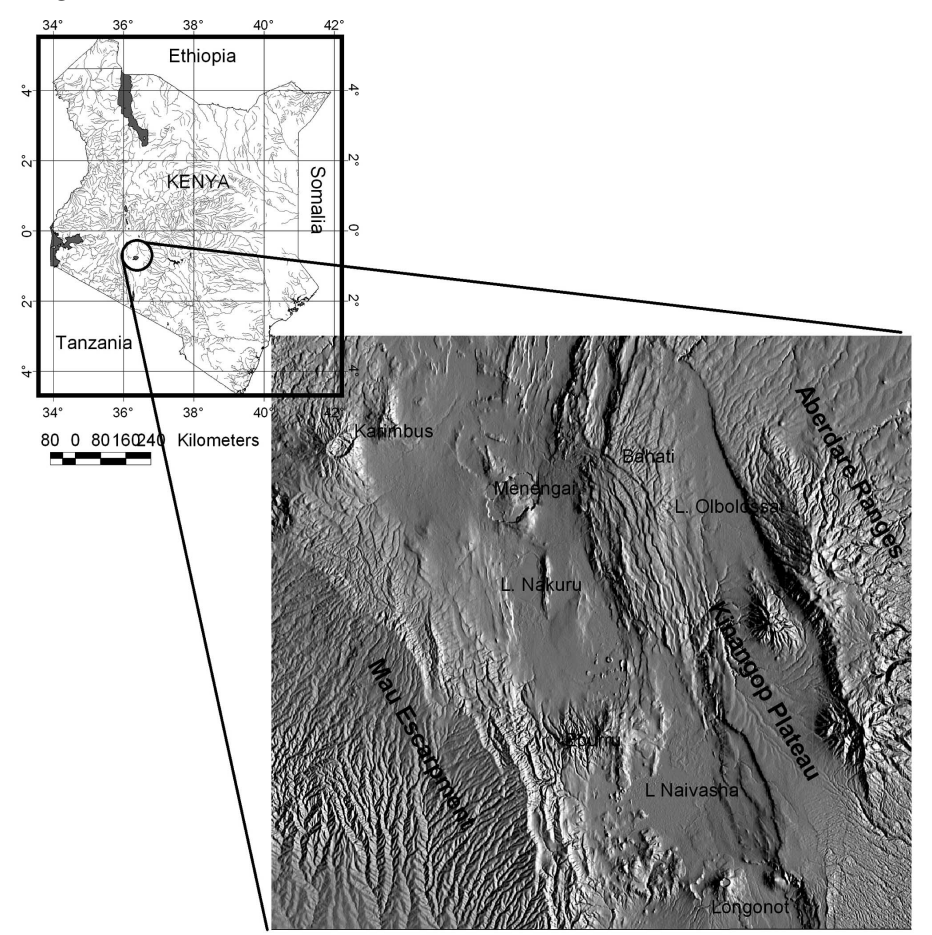

Fig. (1). Location of the study area and SRTM DEM Data of lake Naivasha area (Source: [22]).

changes and their repercussions require careful consideration, both at local and regional level, in order to facilitate the formulation of rational policies that effectively strike a balance between economic development and environmental conservation. Rational policy formulation, however, calls for accessibility to land cover information of sufficient reliability and temporal and geographic detail. The purpose of this study was thus to assess the level of land cover change and the implication of agricultural activities and urban settlement on the lake's water quality. The study's objectives were twofold: to determine the probable driving forces of land use that results in land cover changes in Lake Naivasha drainage basin and; to establish and map the magnitude, rates, nature and spatial distribution of the land cover changes that have occurred in the area and what that means to the quality of water in the lake. Both remote sensing and GIS techniques were employed to collect the pertinent data needed for fulfilling the study's objectives. Multi-temporal satellite data (Landsat TM 1986 and 2000 (ETM) and SPOT 2000) were acquired and field survey conducted from, which land cover sample data were collected using the Global Positioning Systems (GPS) and mobile GIS. The following section presents the study area, materials and methods used in the study and finally the results, discussion and conclusions.

\section{THE STUDY AREA}

Lake Naivasha area is dominated by quaternary volcanic ash and pyroclastic deposits in the plain areas and some volcanic tuff and lava flow in the higher escarpments. The part of the basin around Lake Naivasha is underlain by lacustrine sediment deposits most of which is conspicuously exposed at Ol Njorowa Gorge [10]. The geology of Lake Naivasha area generally shows complex geological structures. Alkaline volcanism 2-3 km thick and composed of pumiceous pyroclastics, ashes, trachytes, ignimbrites, phonolites and phono- litic trachytes, tuffs, agglomerates and acid lava [11, 12] dominate the area. Four major periods of volcanicity and faulting are reported by [13]. Olkaria volcanic complex is dominated by alkali rhyolite lava and pyroclastic rocks. The Lake Elmenteita lava flows are mainly of basalts and ash tuff and the Eburru complex is dominated by trachytes. Widespread trachytic pyroclastics and tuff are located in the Kinangop escarpment. Ol Obonge lava at Eburru, and Ol'lolbutot lava at Olkaria are the youngest of the lava flows reported by [14] to have occurred 2000 years ago. The lithosphere is thin due to geothermal activities in the area $[15,16]$.

The southern part of the catchment of the lake is within the Olkaria volcanic complex. Craters, fumaroles, hot springs and steam vents are found in several places within the Olkaria and Eburru area [17, 18]. The earlier tectonic geology is reflected in the step-faults of Satima and Kinangop generating the Kingop Plateau. Grid faulting has generated the Gilgil Plateau while the Mau escarpment is as a result of fault flextures. The major fault escarpments influence the topography of the rift floor [19] (Fig. 1) and in general reflect the tectonic structure of the East Africa Rift Valley system in Kenya of anatomising and bifurcating faults [20] that influence the drainage flow pattern [21].

The major faults are traceable from satellite images and reveal the structure of the terrain and the lines of surface runoff. The landform features of Mau-Kinangop escarpments, Gilgil plateau, Kinangop plateau and the interior drainage basins of lakes Elmenteita, Naivasha, Ol Bolossat are as shown in the Shuttle Radar Topographic Mission (SRTM) data of the basin [22] (Fig. 1). These landforms greatly influence movement and accumulation of surface and sub-surface waters and subsequently the ground water flow. They also influence the rainfall patterns in the area. 
Meteorological observations records of the Kenya Meteorological Department [23] from six stations (Kwetu Farm, Gilgil - $0^{\circ} 21^{\prime} \mathrm{S} / 36^{\circ} 18^{\prime} \mathrm{E}, 1020.9 \mathrm{~mm}$; Gilgil Railway Station $0^{\circ} 30^{\prime} \mathrm{S} / 36^{\circ} 20^{\prime} \mathrm{E}, \quad 635.5 \mathrm{~mm}$; Kinangop Forest Station $0^{\circ} 35^{\prime} \mathrm{S} / 36^{\circ} 38^{\prime} \mathrm{E}, \quad 1154.6 \mathrm{~mm}$; Naivasha KCC $0^{\circ} 40^{\prime} \mathrm{S} / 36^{\circ} 23^{\prime} \mathrm{E}, 631.2 \mathrm{~mm}$; Naivasha District Officer's $0^{\circ} 43^{\prime} \mathrm{S} / 36^{\circ} 26^{\prime} \mathrm{E}, 670.9 \mathrm{~mm}$; Kerita Forest Station $0^{\circ} 59^{\prime} \mathrm{S} / 36^{\circ} 38^{\prime} \mathrm{E} 1382.1 \mathrm{~mm}$ ) averages over 30 year period range from $630 \mathrm{~mm}$ at the Lake Naivasha area to $1380 \mathrm{~mm}$ at the Aberdare ranges. The rainfall pattern exerts influences on the discharge from the catchment and over the vegetation cover and the pattern of agriculture in this area. Due to hot, dry and windy climate in the Naivasha section of the Rift Valley, annual evaporation loss $(2060 \mathrm{~mm})$ far exceeds the annual mean precipitation of $852 \mathrm{~mm}$. There is also low rainfall reliability making rain-fed agriculture a challenge. The Kenya Meteorological Department (KMD) [23] estimates that the low relative humidity and an average daily maximum temperature of $25{ }^{\circ} \mathrm{C}$ tend to cause annual potential evaporation of 1500-1900 mm/yr which is far in excess of the rainfall [24]. This is also reported by [5]. The area within the rift floor therefore has a semi-arid climate and falls in agroclimatic Zone III and IV [25] and the most suitable farming system would therefore be rangeland agriculture.

Because of volcanic, topographic and climatic influence, there are three different hydro-geological regimes in Lake Naivasha basin, namely:

a). Near surface aquifers that are patched in surface lavas and tuff and pyroclastic sediments at between 50-150 $m$ [26]. These are located along the plateaus and within the riparian areas of Lake Naivasha. These aquifers are normally found in the fractured volcanic rocks and at times along weathered contacts between different lithological units and they are often confined or semi-confined with low storage coefficient.

b). Medium depth aquifers that are a result of interception of drainage from the escarpments by the rift floor fault lines running perpendicular to them. The fault lines are indicative of permeable fractures zones which influence the depth of the aquifers [27]. In the Ndabibi area the aquifers are at approximately 100$300 \mathrm{~m}$ depth and they could be a source of groundwater recharge into Lake Naivasha. The main aquifer is composed of lacustrine volcanic and sedimentary rocks with generally low permeability (12-148 $\mathrm{m} /$ day), though there exists some variations locally [10].

c). Where the groundwater come into contact with deeper fissure and fractures zones they manifest themselves as geothermal resources now under exploitation at Olkaria from 1-2.5 km deep wells [28]. Along Olkaria and Eburru Volcanic Complexes scattered warm springs are seen rising from the lavas and the N-S trending fissures. The fumaroles are discharging from the geothermal reservoirs.

Data from existing boreholes and wells reveal the complex hydro-geological conditions. The depth to aquifers varies throughout the basin but it generally ranges from $1.3 \mathrm{~m}$ at the lake shore area to about $240 \mathrm{~m}$. Estimated hydraulic conductivity average $10 \mathrm{~m} /$ day and well yield on average is 3 $1 / \mathrm{s} / \mathrm{m}[5]$.

Naivasha basin was formerly an integral part of the traditional pastures of the Kenyan pastoral Maasai, with the lake as an important dry season refuge [1]. Following colonization by the British just over one hundred years ago, the basin became a focus for European settlement [29]. The higher parts at the escarpment were mainly used for wheat and cattle and the bottom of the Rift Valley for beef cattle and sisal. Lucerne and other vegetables were grown around Lake Naivasha. Other local communities occupied the higher-altitude areas suitable for rain-fed agriculture.

The urban area of Naivasha, on the north-eastern shores of the lake, with its sewerage treatment works provides the most challenging environmental impacts on the lake [30]. The town has a sewerage-collection system for only part of its area with the rest of the population utilizing pit latrines. The town has open drains which often get flooded, carrying most of the wash-off from the town to the lake during the rains. The sewerage treatment works often breaks down and in instances is non-functional for a long period of time. The overflow from the treatment works is into the lowland area at the shores of the lake.

Lake Naivasha area contains two small national parks (Hells Gate and Longonot) in the vicinity of the lake and the Aberdare National Park is close by and is therefore a tourist destination [1]. The beauty of the area, the diversity of bird and wildlife and the proximity to Nairobi attract many local and overseas visitors $(\approx 40,000$ in 1998) [31]. In 1982 the first geothermal power plant in Africa, KenGen Ol Karia, situated $7 \mathrm{~km}$ south of the lake, became operational, producing about $45 \mathrm{~kW}$ of power [18]. In 2002 an independent power producer started production in an adjacent area, producing $12 \mathrm{~kW}$. In 2005 a second KenGen generation station was commissioned and is currently producing $65 \mathrm{~kW}$ of power.

\section{Naivasha's Population}

Naivasha is one of the fastest growing towns in Kenya. The growth is fuelled by increasing horticulture and floriculture farming business around the lake. Tourist activities in the region, along with rural to urban migration as a result of falling farm incomes from traditional cash crops, have contributed to the growth. The population of those currently living around the lake is estimated at 380,000 people [32]. The population of Naivasha Division, an administrative unit within Lake Naivasha rose by $137 \%$ in 10 years between 1999 and 2009 (Fig. 2).

\section{METHODOLOGY}

Spatial image analysis techniques were used to map the land cover pattern using Landsat TM of 28/1/1986, Landsat ETM of March 2000 and SPOT image of May 2007 centred at Lake Naivasha. The Images were used to delineate the land cover classes. Image preparation, projection, registration and enhancements were done using ERDAS Imagine ${ }^{\circledR}$ image processing software and following a method described by [33-34]. The statistical treatment of the satellite images of 


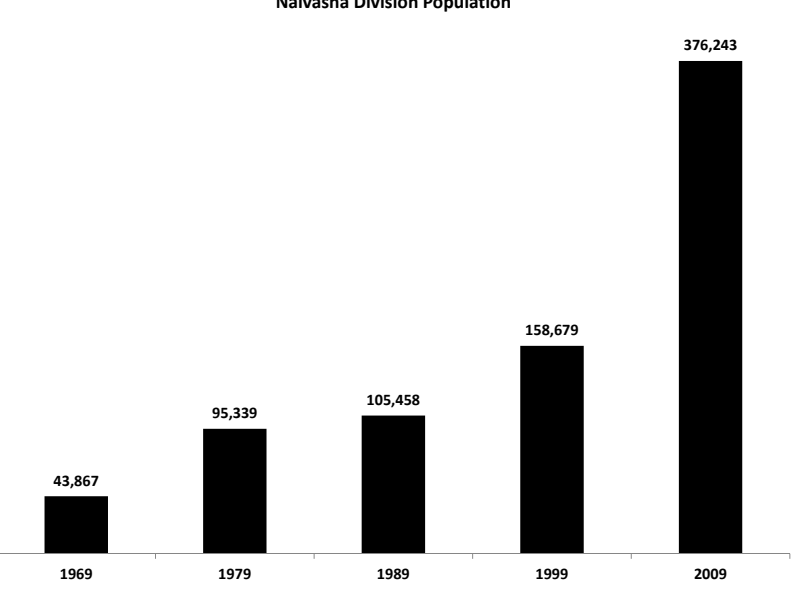

Fig. (2). The population growth of Naivasha Division [32].

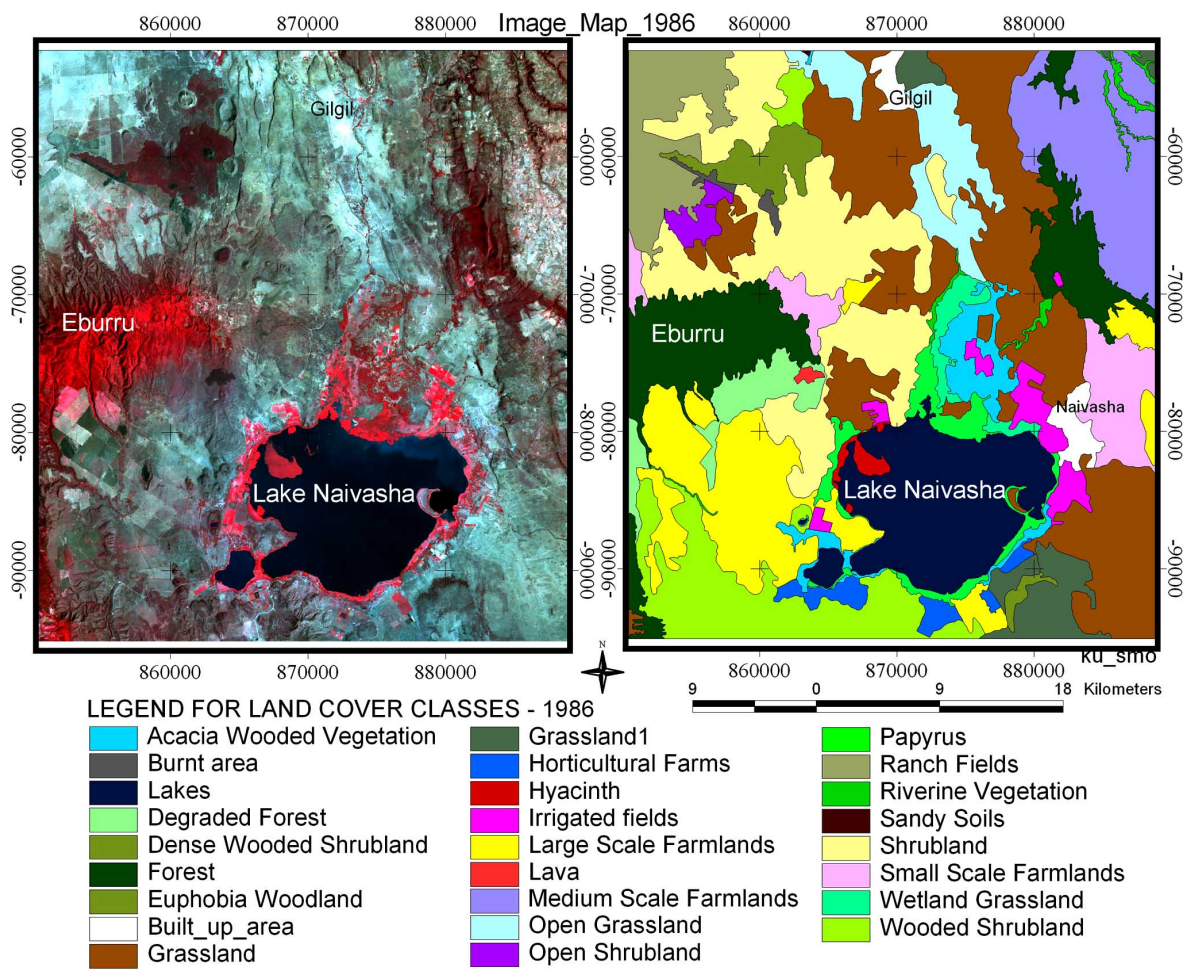

Fig. (3). Image and land cover map extracted from Landsat TM image of January 1986.

the study area used bands $1+2$ (green) average, 3 (red) and 4 (infrared), which showed good contrast of the terrain features. The topography revealed the structure of the terrain and the lines of surface drainage. The vegetation cover mainly occurs on the volcanoes or at the escarpments and along the riparian zones. GEOVIS software was used to cartographically extract the terrain elements that constituted the land cover units. ArcView/ArcGIS $₫$ and the visualization capability of ArcView 3D Analyst were used to further analyze the interpreted data and to compute the areas of the land cover units. The tool was also used to select appropriate symbolization and to change the appearance of the map. Large-scale printouts of FCC were generated for mapping in the field.

Water samples were collected from selected boreholes and parts of the lake. These were used for water quality analysis to determine the effect of anthropogenic activities on the water. The depth to the rest level of the waters in the boreholes was measured to determine the depth to the aquifers. Field observations were made to document the extent of the impacts occasioned by anthropogenic activities. Borehole water level measurements were done during the months of May 2006 and October 2006. Sampling parameters were for in-situ measurement of water characteristics and comprised of temperature, $\mathrm{pH}$, conductivity, total dissolved solids (TDS) and total suspended solids (TSS) measurements.

\section{RESULTS AND DISCUSSIONS}

The high degree of reflectance contrast of the study area parameters enabled extraction of 34 terrain parameters (land cover units) shown in Figs. (3, 4 and 5) and Table 1. The topographic variations and the vegetation cover influenced 


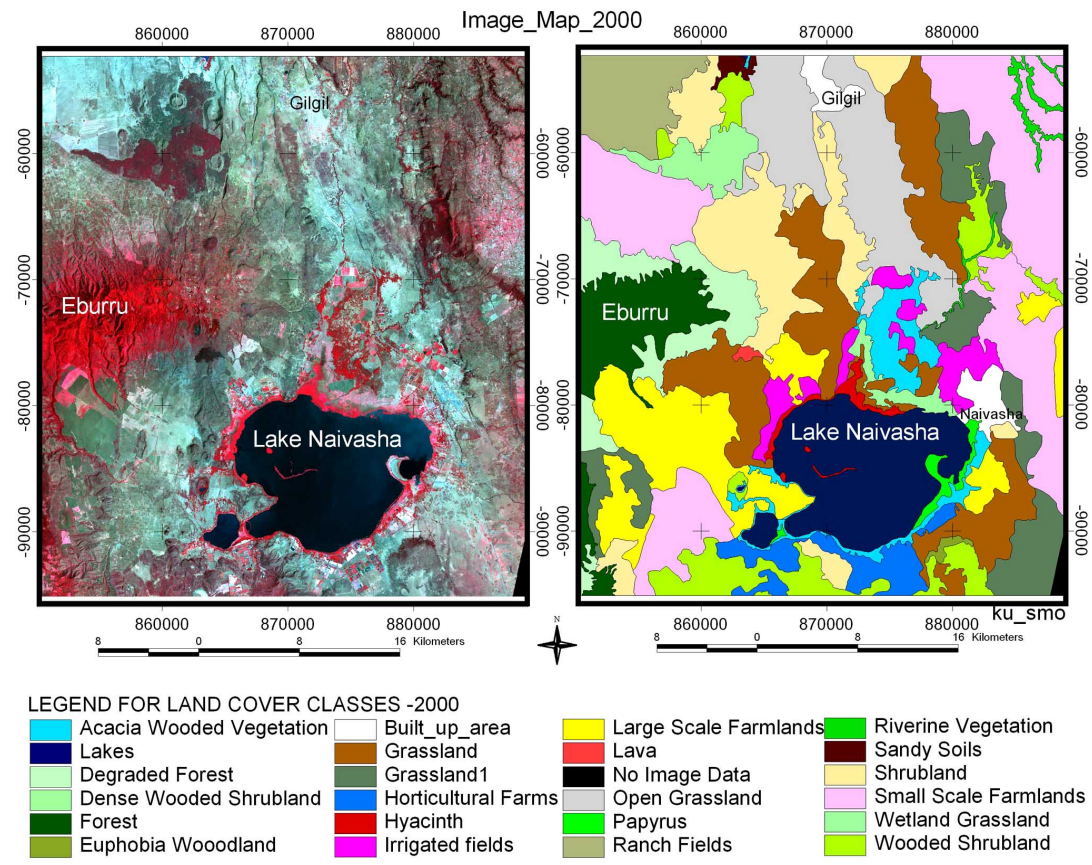

Fig. (4). Image and land cover map extracted from Landsat ETM image of March 2000.

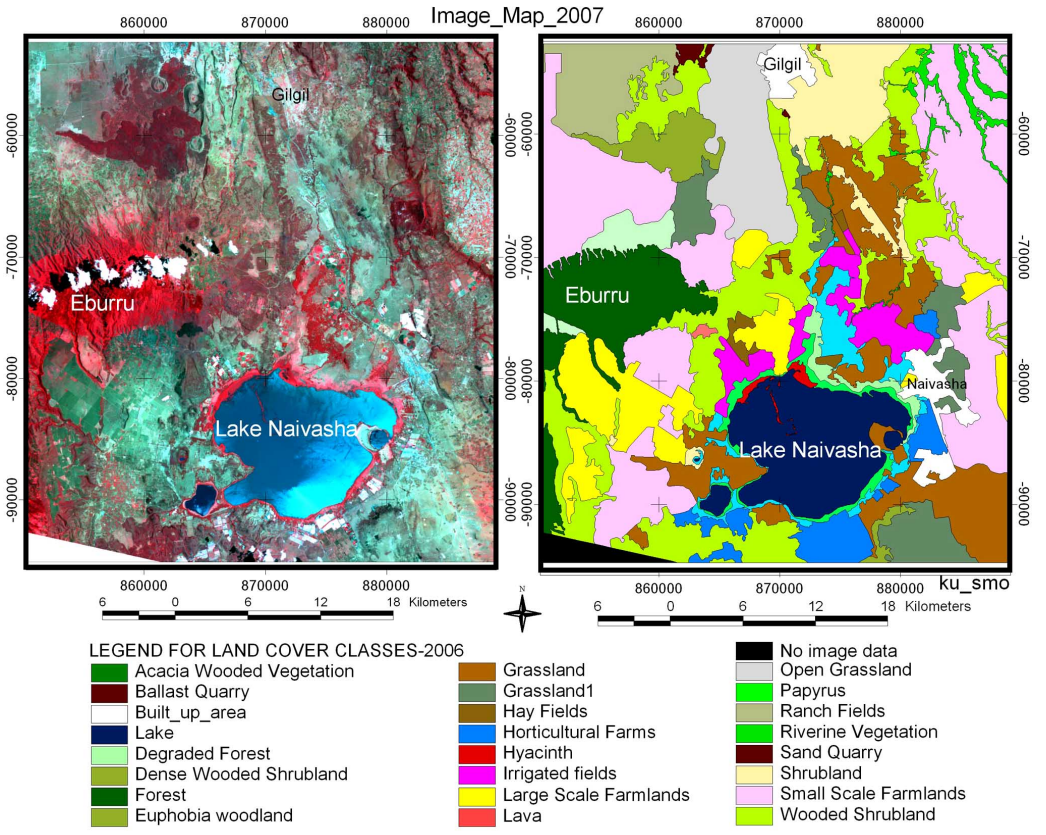

Fig. (5). Image and land cover map extracted from SPOT image of May 2007.

the nature of the parameters. There was strong variance among water, riparian vegetation, deciduous bush, bare ground, horticultural cultivation and the irrigated land units, papyrus and water hyacinth thus enabling their delineation. The river drainage lines dissecting through the escarpments were also easily delineated. The image data was visually interpreted based on the tonal values, texture and structure based on the principal discussed by [35]. The areas with similar characteristics were grouped to one class and the delineation made. The area coverage of the 34 specific land cover classes identified was computed and the data regrouped into 9 broad classes highlighted in grey in Table $\mathbf{1}$.
The table gives a broad picture of the changes that have taken place in the basin.

The interpretation made from the time series image data of 1986, 2000, 2007 shows that the wider Lake Naivasha Basin is being used for rain-fed small scale and large scale subsistence and cash crops cultivation. This area is mainly located in Kinangop Plateau and the Ndabibi Plain. It can also be deduced that the riparian area around Lake Naivasha is mainly under horticulture farming. On comparing the images of 1986 and 2007 for the $1644 \mathrm{~km}^{2}$ under study, it is apparent that: 
Table 1. 34 Land Cover Units Extracted from Satellite Imagery of the Area for the Dates Shown

\begin{tabular}{|c|c|c|c|c|c|c|}
\hline SUB_CLASSES & $1986\left(\mathrm{~km}^{2}\right)$ & $2000\left(\mathbf{k m}^{2}\right)$ & $2006\left(\mathrm{~km}^{2}\right)$ & $\begin{array}{c}\text { 1986-2000\% } \\
\text { Increase }\end{array}$ & $\begin{array}{l}\text { 2000-2006 } \\
\% \text { Increase }\end{array}$ & $\begin{array}{c}\text { 1986-2006\% } \\
\text { Increase }\end{array}$ \\
\hline Acacia Wooded Vegetation & 37.1 & 46.2 & 35.6 & 24.3 & -22.9 & -4.1 \\
\hline Euphobia Woodland & 4.1 & 2.7 & 4.9 & -34.5 & 81.9 & 19.1 \\
\hline Wooded Shrubland & 111.7 & 79.6 & 226.9 & -28.7 & 185.0 & 103.2 \\
\hline Degraded Forest & 33.0 & 65.9 & 20.2 & 99.5 & -69.3 & -38.9 \\
\hline Dense Wooded Shrubland & 27.6 & 28.9 & 32.9 & 4.6 & 14.1 & 19.3 \\
\hline Eburru Forest & 83.5 & 66.0 & 88.7 & -21.0 & 34.4 & 6.2 \\
\hline Mau East Forest & 8.6 & 9.7 & 9.4 & 11.9 & -2.9 & 8.6 \\
\hline Kinangop Forest & 49.5 & - & - & Present & Obliterated & Obliterated \\
\hline Riverine Vegetation & 10.7 & 10.9 & 19.1 & 1.5 & 75.5 & 78.0 \\
\hline Dense vegetation & 365.9 & 309.8 & 437.7 & -15.4 & 41.3 & 19.6 \\
\hline Grassland & 311.9 & 192.1 & 172.6 & -38.4 & -10.2 & -44.7 \\
\hline Grassland1 & 43.3 & 101.2 & 70.6 & 133.6 & -30.3 & 62.9 \\
\hline Hay Fields & - & - & 7.7 & - & - & - \\
\hline Open Grassland & 59.8 & 145.4 & 84.8 & 143.1 & -41.7 & 41.8 \\
\hline Open Shrubland & 11.0 & - & - & - & - & - \\
\hline Shrubland & 201.3 & 141.7 & 72.7 & -29.6 & -48.7 & -63.9 \\
\hline Ranch Fields & 68.9 & 57.1 & 57.4 & -17.1 & 0.4 & -16.8 \\
\hline Grassland & 696.2 & 637.5 & 465.7 & -8.43 & -26.9 & -33.1 \\
\hline Hyacinth & 6.6 & 9.0 & 4.4 & 36.9 & -51.3 & -33.3 \\
\hline Papyrus & 31.9 & 8.2 & 17.7 & 74.4 & 116.6 & -44.6 \\
\hline Wetland Grassland & 16.1 & 12.2 & 12.2 & - & - & - \\
\hline Wetlands & 54.6 & 29.3 & 34.3 & -46.30 & 17.0 & -37.2 \\
\hline Crater Lake & 0.2 & 0.2 & 0.1 & 0.0 & -40.0 & -40.0 \\
\hline Lake Elmenteita & 0.0 & 0.1 & - & - & - & Receded \\
\hline Lake Naivasha & 134.9 & 131.2 & 117.5 & -2.8 & -10.4 & -12.9 \\
\hline Lake Oloidien & 5.5 & 5.4 & 4.3 & -2.1 & -21.0 & -22.6 \\
\hline Surface water & 140.7 & 136.9 & 121.9 & -2.60 & -10.91 & -13.32 \\
\hline Horticultural Farms & 17.7 & 38.9 & 45.5 & 119.9 & 16.9 & 157.0 \\
\hline Irrigated fields & 27.4 & 39.3 & 46.2 & 43,41 & 17.5 & 68.5 \\
\hline Irrigation & 45.1 & 78.2 & 91.7 & 73.43 & 17.2 & 103.3 \\
\hline Large Scale Farmlands & 145.5 & 140.7 & 105.3 & -3.3 & -25.2 & -27.6 \\
\hline Medium Scale Farmlands & 114.1 & - & - & - & - & - \\
\hline Large Farmlands & 259.6 & 140.7 & 105.3 & -45.80 & -25.2 & -59.4 \\
\hline Small Scale Farmlands & 58.9 & 277.8 & 329.2 & 372.0 & 18.5 & 459.4 \\
\hline FARMLANDS & 318.5 & 418.5 & 434.5 & 31.40 & 3.8 & 38.4 \\
\hline Gilgil Township & 7.5 & 10.7 & 14.2 & 41.2 & 33.7 & 88.8 \\
\hline Naivasha Township & 12.6 & 14.9 & 24.3 & 17.6 & 63.3 & 92.2 \\
\hline Urban & 20.2 & 25.5 & 38.5 & 26.44 & 51.0 & 90.9 \\
\hline Lava & 1.6 & 1.7 & 1.5 & 8.0 & -14.1 & -7.3 \\
\hline Sandy Soils & 0.1 & 4.6 & 4.2 & $3,184.9$ & -14.0 & $2,723.7$ \\
\hline Ballast Quarry & - & - & 0.3 & - & - & New \\
\hline Rock & 1.7 & 6.3 & 5.9 & 262.18 & -5.95 & 240.64 \\
\hline Burnt area and No Image Data & 4.7 & 2.5 & 13.9 & Event & - & - \\
\hline Total Area & $1,650.3$ & $1,644.3$ & & & & \\
\hline
\end{tabular}




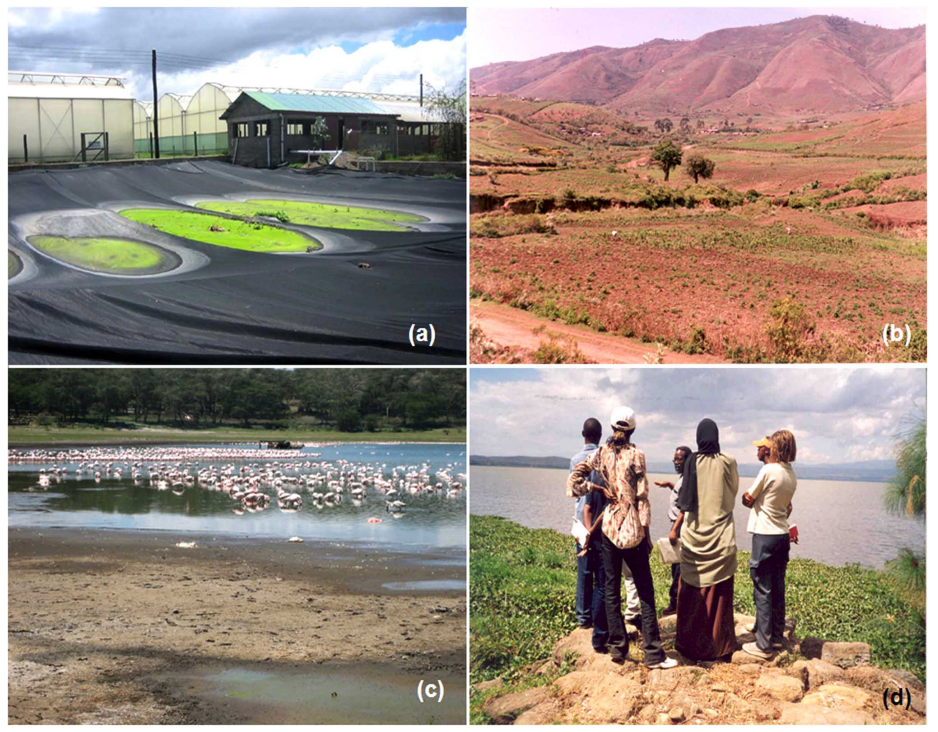

Fig. (6). Impacts in Lake Naivasha area from the changing land use patterns. (a) Horticulture activities; (b) intense arable farming in Ndabibi area; (c) emergence of flamingoes in the Small Lake (Lake Oloidien) - note the receding water levels: (d) Fringe of water hyacinth in Lake Naivasha with higher turbidity of the water.

- Most of the rift floor is covered by thick grassland, scattered grass and scattered bushes which due to increased agriculture has reduced by $33 \%$ from $696 \mathrm{~km}^{2}$ in 1986 to $466 \mathrm{~km}^{2}$ in 2006.

- The area of the lake classified as open water has decreased from $135 \mathrm{~km}^{2}$ in 1986 to $118 \mathrm{~km}^{2}$ in 2006 (a decrease of 13\%). Similar levels $\left(137.3 \mathrm{~km}^{2}-1986\right.$ and $\left.112.6 \mathrm{~km}^{2}-2001\right)$ are documented by [36]

- The horticultural and irrigation activities around the lake have increased from $45 \mathrm{~km}^{2}$ to $92 \mathrm{~km}^{2}$ (103\%) in the same period.

- Lake Naivasha is fringed by a belt of papyrus and yellow fever acacia (Acacia xanthophloea) whose overall acreage has decreased by $37 \%$ from $55 \mathrm{~km}^{2}$ to 34 $\mathrm{km}^{2}$.

- Farming activities have seen a change from large scale farming to small scale farming and overall more land has been put into agriculture with an increase of $38 \%$ from $318 \mathrm{~km}^{2}$ to $435 \mathrm{~km}^{2}$. Overall, small scale farming has increased from 59 to $329 \mathrm{~km}^{2}$ an increase of $459 \%$.

- The urban settlement have grown by $90 \%$ (from 20 to $39 \mathrm{~km}^{2}$ ).

- The $49 \mathrm{~km}^{2}$ of forest cover present at the Kinangop plateau in 1986 was completely obliterated by the year 2000.

The land cover interpretation indicates that since 1986 the nature of agriculture around the lake and its catchment area has changed drastically from ranching based agriculture to horticultural cultivation (Fig. 6a) and small scale subsistence agriculture (Fig. 6b). The commercial activities surrounding the floriculture industry provides employment opportunities and has therefore led to an influx of people into Naivasha Township and its surrounding area. Naivasha is one of the most populated divisions in the country with a population of 376,243 and a population density of 124 persons per square kilometer [30]. There is a tremendous rise in population from 158,679 in 1999 to 376,243 in 2009 . The majority of the population increment is due to immigration for employment opportunities at the flower farms and due to displacement from other areas of the country. The riparian area of the lake must support the large population and its vitality and sustainability has therefore raised concern. The formerly traditionally livestock rearing and ranching area with the lake being used for watering [27] has given way to large irrigated horticulture around the lake and arable farming in Ndabibi (Fig. 6b) and the Kinangop area. The farming activities have impacted on the natural rhythm of the Lake in terms of water level fluctuations as reflected in the decreased surface area of the lake $-135 \mathrm{~km}^{2}$ in 1986 to $118 \mathrm{~km}^{2}$ in 2006 also reported by [8] as fluctuating between 138-297 $\mathrm{km}^{2}$. The lake's ecology is also changing as reflected in new faunal characteristic with recording of the presence of flamingoes in Lake Oloidien, - the Small Lake in the Lake Naivasha ecosystem system (Fig. 6c).

The ecology of the lake is also seen in the persistent presence of water hyacinth [36] (Fig. 6d). The presence of water hyacinth and the sediment loading has increased the cost of operation and treatment of domestic water supply which has seen the Naivasha Municipal Council reduce its water supply capacity by $30 \%$ from $10,000 \mathrm{~m}^{3}$ to $7,000 \mathrm{~m}^{3}$. Generally, the water has high turbidity requiring full convectional treatment before domestic use. The town has been growing at a very high rate while provision of basic facilities has not expanded at the same rate to serve the population making the municipality unable to cope with the growth. Already Naivasha Town is a water deficit area [1]. The water supply can only meet 50 per cent of the water requirements. Other demographic pressures are mainly peremptory exploitation of the forest cover and other vegetation for agriculture, grazing, sources of construction materials, food and fuel wood. 
Table 2. Summary of in Situ Measurement of the Properties of Water Samples from Various Water Sources in the Lake Naivasha Basin

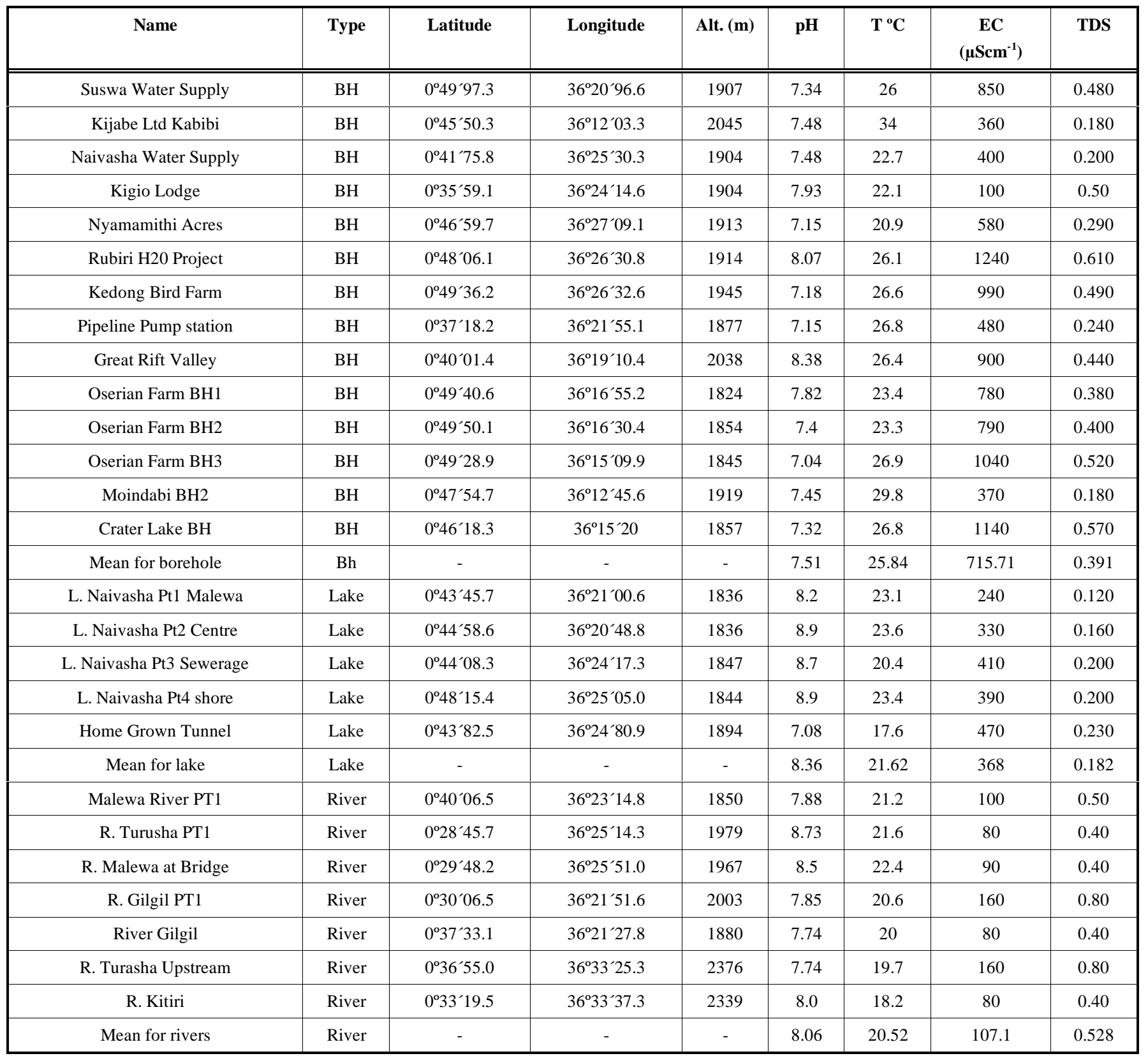

Water level changes and pollution in Lake Naivasha has been of wider interest over many years, initially because of scientific curiosity about the causes of extreme fluctuation [37-41] but lately for its economic value to irrigation and supply of water for domestic consumption and irrigation. The receding lake could be as a result of higher evapotranspiration, higher sediment loading and water abstraction for irrigation activities. These activities have lead to the change in the chemistry of the water in the lake which from the in situ measurements shown in Table $\mathbf{2}$ has a mean conductivity of $368 \mu \mathrm{S} . \mathrm{cm}^{-1}$ compared to that previously recorded by [5]. The borehole waters have a mean conductivity of 715.7 $\mu \mathrm{Scm}^{-1}$ and river waters $107.1 \mu \mathrm{Scm}^{-1}$. These values are rather high for drinking water. From the $\mathrm{pH}$ measurements (8.36), the lake water tends to be alkaline. Lake Oloidien now supports the blue-green algae and tiny crustaceans, a suitable food for flamingoes that now inhabit that part of the lake (See Fig. 6c). As seen from the water characteristic (Table 2), the groundwater chemistry of boreholes indicate that Lake Naivasha catchment area has different water characteristics from the lake's waters. From the conductivity and $\mathrm{pH}$ values, the water quality reflects the complex volcanic geology of the watershed.

Because of the low depth of the lake (mean depth of 6.5 $\mathrm{m}[8,42])$ it means that relatively small amounts of rainfall result in large changes in the area and volume of the lake. The shrinkage of the lake margins affects the faunal biodiversity and the fish breeding sites and pattern as reported by $[36,43-45]$. In addition the increasing agricultural activities 
and urban settlements around the lake are affecting the discharge and surface runoff into the lake. These activities also introduce pollution inputs which may significantly affect the vitality of the lake in terms of its biodiversity [42]. The consumptive use of water from Lake Naivasha for irrigation, domestic, urban and industrial use is seen as the major cause of pressure on the freshwater resource.

The presence of many large scale horticultural interests relies heavily on irrigation water, giving rise to concerns over its impact on the lake's water level and water quality. Even with the introduction of the much more efficient drip irrigation technologies in the greenhouse environment, there is still concerns on the challenges facing the lake through abstraction and discharge. In addition agricultural activities have led to opening up of fault gushes and gulleys (see Fig. 6b), interfering with surface runoff and reducing the discharge into the lake. The depletion of the forests on the Kinangop, Mau escarpments and Eburru volcanic complex has led to severe erosion damage seen on the images from the deep gulleys hundreds of meters long. Agriculture has a heavy bearing on erosion in the area as seen from the turbidity of the water (Fig. 6d). The abstraction rates from Lake Naivasha itself have not been conclusively established and would require each of the riparian farmers declaring the quantities abstracted through metred measurements. This has not been adequately addressed even with the existing legislation requiring that any farmer abstracting water from public utilities to declare their rates of abstraction [1,8]. Any efforts towards ascertaining this are always met with resistance from the farmers.

\section{CONCLUSIONS}

Lake Naivasha is of immense national and local importance with her water supporting $70-75 \%$ of national cut flower production. The removal of vegetation and increase in agricultural area within the lake basin has however led to severe land cover change and erosion damage. The main lake show irregular changes of volume which also affects the chemistry, salinity, productivity, bio-chemical oxygen demand and nutrients in the lake leading to vulnerability of the biodiversity. Studies reviewed during this study indicates a lake experiencing many major changes, both natural and anthropogenic over time-scales from diurnal to decadal or longer, with effects ranging from local accumulations of algal cells to complete drying. The quality and health of the lake shows a seasonal shift between diatom and cyanobacterial dominance indicating increased nutrient loading on the lake. The major nutrient input being from Malewa River although waste discharge from the high population and increased intensive agricultural activities that use pesticides and fertilizers raises concerns. The health of the lake is compromised as seen from the hydrophytic species succession of Salvinia molesta (water fern), Eichhornia crassipes (water hyacinth) Cyperus papyrus (papyrus), and Acacia dreponalopium (Yellow Fever Acacia). Use of satellite data to assess the rate of change of anthropogenic activities has lead to improved mapping and quantification of the land cover units. The implication of land use trends and practices mapped from Landsat and SPOT data is made apparent when SRTM DEM data and field observation data is integrated.
The image and the DEM model stresses the importance of morphotectonic control on the land cover changes taking place in the basin. The data is therefore valuable in addressing the important question of environmental degradation in the Lake Naivasha basin.

The quantity and quality of water getting into the lake is further compromised from lack of sewerage treatment in Naivasha Township and runoff from the horticultural farms. The porosity and permeability of the geological formations also mean that there is probable groundwater contamination. The rising population and vulnerability of the productive wetland areas of the lake's riparian environment means that there is substantial challenge for sustainable development of the lake's resources. The long-term viability of the smallscale farming to support the community has lead to new challenges in form of intensification of agriculture and therefore increased farm input. Through the intervention efforts of the Lake Naivasha Riparian Association (LNRA) a buffer zone below the $1906 \mathrm{~m}$ contour has been identified as an off limit area to all construction or cultivation but the challenge however is the implementation of this intervention strategy.

\section{CONFLICT OF INTEREST}

\section{None declared.}

\section{ACKNOWLEDGEMENTS}

The fieldwork for this study was conducted in 2006 and was supported by the MAWARI project on Sustainable Management of Groundwater Resources in the East Africa Rift supported by CIFEG (International Centre for Training and Exchanges in the Geosciences) funds. The SPOT image of 2006 was acquired using the same funds. Acknowledgment is given to initial support by USHEPiA (Universities Sciences, Humanities and Engineering partnerships in Africa) of the University of Cape Town (UCT) which in 2002 supported the purchase of Landsat satellite images for 2002 and 1986. DAAD through the University of Siegen and Kenyatta University are thanked for support to the DAAD International Seminar/Workshop "Topics of Integrated Water Resources Management” Bagamoyo, Tanzania.

\section{REFERENCES}

[1] LNRA, Lake Naivasha Management Plan. Lake Naivasha Riparian Association, Naivasha, Kenya, 77p: 1999

[2] D.M. Harper, K.M. Mavuti and S.M. Muchiri, "Ecology and management of Lake Naivasha, Kenya, in relation to climatic change, alien species' introduction and agricultural development", Environ Conserv, vol. 17, pp. 328-335, 1990.

[3] (Accessed 12/12/2010). Available at: www.wetlands.org/RDB/Ramsar_Dir/Kenya/ke002D02.htm

[4] R. Becht, E. Odada and S. Higgins, Lake Naivasha: "Experience and Lessons Learned Brief". The World Bank. (Accessed 10/10/2010). Available at http://www.ilec.or.jp/eg/lbmi/reports/17_Lake_Naivasha_27February2006.pdf: 2006

[5] J. Gaudet and J.M. Melack, "Major ion chemistry in a tropical African lake basin", Freshwater Biol, vol. 11, pp. 309-333, 1981.

[6] J. Goldson, A three phase environmental impact study of recent developments around Lake Naivasha. Lake Naivasha Riparian Owner's Association, Naivasha, p. 109, 1993.

[7] N. Kitaka, D.M. Harper and K.M. Mavuti, "Phosphorus inputs to Lake Naivasha, Kenya, from its catchment and the trophic state of the lake", Hydrobiologia, vol. 488 (168), pp. 73-80, 2002.

[8] Republic of Kenya, Rift Valley Catchment Area Catchment Management Strategy. Water Resources Management Authority: Kenya, 85p: 2008. 
[9] J.J. Gaudiet and A. Falconer. "Remote sensing for tropical freshwater bodies: The problem of floating islands on lake Naivasha”, Regional Remote Sensing Centre: Nairobi, 1982.

[10] M.C.G. Clarke, D.G. Woodhall, D. Allen and W.G. Darling "Geological, volcanological and hydrological controls on the occurrence of geothermal activity in the area surrounding Lake $\mathrm{Na}$ ivasha, Kenya”, Ministry of Energy: Nairobi, Kenya, pp.138, 1990.

[11] B.H. Baker and J. G. Mitchell, "Volcanic Stratigraphy and Geochronology of the Kedong-Olorgesailie area and the evolution of the south Kenya Rift Valley", J. Geol. Soc., London, vol. 132, pp. 407-484, 1976.

[12] B.H. Baker, L.A.J. Williams, J.A. Miller and F.J. Fitch, "Sequence and Geochronology of the Kenya Rift Volcanics”, Tectonophysics, vol. 11, pp. 191-212, 1977.

[13] B.H. Baker, "Tectonics and volcanism of the southern Rift Valley and its influence on rift sedimentation", Geol. Soc. special publication, vol. 25, pp. 45-57, 1986.

[14] A.O. Thompson and R.G. Dodson, "Geology of Naivasha area", Report No. 55, Geological Survey of Kenya: Nairobi, Kenya, pp. 80: 1963.

[15] R.F.Wendlandt and P. Morgan, "Lithosphere thinning associated with rifting in East Africa", Nature, London, vol. 298, pp. 734-736, 1982.

[16] C.J. Ebinger, T.D. Bechtel, D.W. Forsyth and C.O. Bowin, "Effective elastic thickness beneath the East African and Afar plateaus and the dynamics of the uplifts", J. Geophys. Res., 94 (B3), pp. 2883-2901, 1987.

[17] S.M. Onywere. "Structural analysis of the drainage basin of Kenyan Rift Valley Lakes within the Aberdare Detachment using satellite data", GIS and field observations, PhD Thesis, Department of Geology, University of Nairobi: Nairobi, Kenya, pp.200, 1997.

[18] C.F. Burgess, "Kenya Rift Valley Geothermal project: hydrogeology and geothermics of the Magadi-Longonot sector", BGS Report WD/05/86/5, KP\&L, Ministry of Energy: Nairobi, Kenya, 1986.

[19] S.M. Onywere, "Morphological Structure and the Anthropogenic Dynamics in the Lake Naivasha Drainage Basin and its Implications to Water Flows". fwu.fb10.uni-siegen.de/bkd/deutsch/Publikation/Texte_FWU/volumen03/FWU - Water Resources Publications and University of Siegen, series 4, 2005.

[20] J. Chorowicz, "Dynamics of the different basin types in East African Rift”, J. Afr. Earth. Sci., 10 (1/2), pp. 271-283, 1990.

[21] L.E. Ase, K. Sernbo and S. Per, "Studies of Lake Naivasha, Kenya, and its drainage area”, Stockholms Universitet Naturgeografiska institutionen, Stockholm, vol. 91, pp. 106, 1986.

[22] USGS/EROS Data Center, "The Shuttle Radar Topography Mission (SRTM) ", NASA's Jet Propulsion Laboratory (JPL), Pasadena, CA, for NASA's Earth Science Enterprise, Washington, D.C., Geodata Warehouse Africa, 2000

[23] Kenya Meteorological Department (KMD), Climatological Statistics for Kenya. KMD: Nairobi, 2001.

[24] A. P. Lukmann, "Regional impact of climate change and variability of water resources: case study, lake naivasha basin, kenya", MSc. Thesis, International Institute for Aerospace Survey and Earth Science, Enschede, The Netherlands, 2003.

[25] W.G. Sombrock, H. M. H. Braun and B. J. A. Van Der Pouv, Eds., Exploratory soil map and agro-climatic zone map for Kenya. Hague: Cartoprint BV, 1982.

[26] L.E. Ase, "A note on the water budget of Lake Naivasha". Geographiska Annaler (69A), pp. 415-429, 1987.

[27] B.D. Bone, "The geological evolution of the S.W. Naivasha volcanic complex", Kenya. PhD Thesis, University of Lancaster, UK, 1985 .
[28] B.M. Kubo, "Environmental Management of Olkaria Geothermal Project”, Kenya, paper presented in the Geothermal Conference, Nairobi-Kenya, 2002.

[29] D.J. Campbell, D.P. Lusch, T. Smucker, and E.E. Wangui, "Root causes of land use change in the Loitoktok area, Kajiado district, Kenya", LUCID Working paper series No.19, 2003

[30] R. Becht and D.M. Harper, "Towards an understanding of human impact upon the hydrology of Lake Naivasha", Hydrobiologia, vol. 488 (168), pp. 1-11, 2002.

[31] M. Everard and D.M. Harper, "Towards the sustainability of the Lake Naivasha Ramsar site and its catchment", Hydrobiologia, vol. 488 (168), pp. 198-210, 2002.

[32] Kenya National Bureau of Statistics, "Kenya Population and Housing Census 2009", Ministry of State for Planning, National Development and Vision 2030, Nairobi, Kenya, 2010.

[33] B.A. Bradley and M. T. O'sullivan, "Assessing the short-term impacts of changing grazing regime at the landscape scale with remote sensing”, Int. J. Remote. Sens., vol. 32:20, pp. 5797-5813, 2011

[34] Y.O. Ouma and R. Tateishi, "A water index for rapid mapping of shoreline changes of five East African Rift Valley lakes: an empirical analysis using Landsat TM and ETM+ data ", Int. J. Remote. Sens., vol. $27: 15$, pp. $3153-3181,2006$

[35] T.M. Lillesand and R.W. Kiefer, "Remote sensing and photointerpretation", $3^{\text {rd }}$ ed. John Wiley and Sons: New York. p. 750 1994.

[34] J.M. Mironga, "The Spreading Patterns and Environmental Implications of Water Hyacinth (Eichhornia crassipes) Infestations in Lake Naivasha, Kenya", PhD Thesis, Department of Geography, Egerton University, Njoro, Kenya, 2008.

[36] C. K. Washbourne-Kamau, "Late Quaternary Lakes in the Nakuru-Elmenteita Basin, Kenya", Geogr. J., vol. 137, pp. 522-535, 1971

[37] J.L. Richardson, "Changes in level of Lake Naivasha, Kenya, during postglacial times”, Nature, London, vol. 209 (5020), pp. 290-291, 1966.

[38] J. L. Richardson, and A. E. Richardson, "History of an African Rift Lake and its climatic implications", Ecol. Monogr., 421, pp. 499-534, 1972.

[39] P. Hickley and D.M. Harper, "Fish community and habitat changes in the artificially stocked fishery of Lake Naivasha, Kenya", In: Management and ecology of Lake and Reservoir Fisheries (I.G. Cowx, ed.) Oxford: Fishing News Books, Blackwell Scientific Publications, pp. 242-254, 2002.

[40] D.S. Hubble and D.M. Harper, "Phytoplankton community structure and succession in the water column of Lake Naivasha, Kenya: a shallow tropical lake", Hydrobiologia 488 (1/3), pp. 401-415, 2002 .

[41] D.S. Hubble and D.M. Harper, "What defines a 'healthy' lake? Evidence from Lake Naivasha, Kenya", Aquat Ecosyst Health \& Manag, 4:3, pp. 243-250, 2001.

[42] P. Aloo, "Anthropogenic Impact on fisheries resources of lake naivasha", In: Limnology, Climatology, Paleoclimatology of the East African Lake Ed by T. C. Johnson, E. Odada and Gordon Breach Publishers, Amsterdam, The Netherlands, pp. 325-335, 1996.

[43] P. Hickley, R.G. Bailey, D.M. Harper, R. Kundu, S.M. Muchiri, R. North and A. Taylor, "The status and future of the Lake Naivasha fishery, Kenya", Hydrobiologia, vol. 488 (168), pp. 181-190, 2002.

[44] P. Hickley, S. M. Muchiri, J.R. Britton and R.R. Boar, "Discovery of carp (Cyprinus carpio) in the already stressed fishery of Lake Naivasha, Kenya". Fish manag Ecol, vol. 11, pp. 139-142, 2004.

[45] G. E. Otiang'a-Owiti and I. A. Oswe, "Human impact on lake ecosystems: the case of Lake Naivasha, Kenya", Afr. J. Aquat Sci., vol. 32:1, pp. 79-88, 2007.

Received: June 13, 2011 Revised: October 16, 2011 Accepted: November 02, 2011

(C) Onywere et al.; Licensee Bentham Open.

This is an open access article licensed under the terms of the Creative Commons Attribution Non-Commercial License (http://creativecommons.org/licenses/by-nc/3.0/g) which permits unrestricted, non-commercial use, distribution and reproduction in any medium, provided the work is properly cited. 